\title{
Communication
}

\section{Dectin-1 and TIM3 Expression in Deep Vein Thrombosis of Lower Limbs (DVTLL)}

\author{
Vincenza Barresi ${ }^{1} \mathbb{D}$, Salvatore Napoli ${ }^{1,+}$, Giorgia Spampinato ${ }^{1,+}{ }^{\mathbb{D}}$, \\ Daniele Filippo Condorelli ${ }^{1}$ (D) and Salvatore Santo Signorelli ${ }^{2, *(D)}$ \\ 1 Department of Biomedical and Biotechnological Sciences, Section of Medical Biochemistry, \\ University of Catania, 95123 Catania, Italy; barregi@unict.it (V.B.); napo.salvo@gmail.com (S.N.); \\ giorgiaspampinato@unict.it (G.S.); daniele.condorelli@unict.it (D.F.C.) \\ 2 Department of Clinical and Experimental Medicine, University of Catania, 95123 Catania, Italy \\ * Correspondence: ssignore@unict.it \\ + These authors contributed equally to this work.
}

Received: 4 August 2020; Accepted: 24 October 2020; Published: 28 October 2020

\begin{abstract}
The pathophysiological mechanisms of venous thromboembolism are venous stasis, endothelial damage, and hypercoagulability, while less attention has been given to the role of both innate and native immunity. In this paper, we investigate the involvement of the activated immune system detected through some indicators such as TIM3 and Dectin-1 expressed by T lymphocytes. TIM3 and Dectin-1, two surface molecules that regulate the fine-tuning of innate and adaptive immune responses, were evaluated in patients affected by deep vein thrombosis of lower limbs (DVTLL). $\mathrm{CD}^{+}, \mathrm{CD}^{+}$and $\mathrm{CD}^{+} \mathrm{T}$ lymphocytes obtained from patients affected by DVTLL were analysed using fluorescence-conjugated antibodies for TIM3 and Dectin-1 by an imaging flow cytometer. DVTLL patients showed a higher number of $\mathrm{CD}^{+}$and $\mathrm{CD}^{+} \mathrm{T}$ lymphocytes. TIM3 expression in T lymphocytes was very low in both DVTLL patients and controls. On the contrary, an increase in Dectin- $1^{+}$cells among CD4 ${ }^{+}$and CD8 ${ }^{+}$T lymphocytes from DVTLL patients was observed. Dectin- 1 is known to play a role in inflammation and immunity and our result suggests its potential involvement in thrombotic venous disease.
\end{abstract}

Keywords: deep vein thrombosis; inflammation; immunity; T lymphocyte; Dectin-1; TIM3

\section{Introduction}

There is a growing interest in venous thromboembolism (VTE) because it is a potential and serious consequence in patients affected by solid or haematologic cancer hospitalised for surgical or orthopaedic interventions, or who suffer from chronic or acute medical diseases such as heart failure, chronic obstructive pulmonary disease (COPD) [1,2] and asthma [3,4]. VTE is now ranked as the third most common cause of disability and cardiovascular death worldwide [5,6]. Endothelium dysfunction, blood stasis and hypercoagulability, which are included in Virchow's triad, are still considered hardpoints in the pathophysiology of VTE. The aforementioned triad activates the coagulative cascade, by disrupting the fibrin structure, favouring blood cell (leucocyte, platelet) adhesion and promoting cell-derived microvesicles [7]. A growing body of evidence has shown the role played by inflammation in the initiation of a venous thrombus, the renewal of tissue integrity and function of venous circulation [6,8]. Although the role of inflammation has been analysed and the presence of T cells in the thrombus has been demonstrated [9], current guidelines for the treatment of VTE suggest using anticoagulants as the first line of treatment in VTE. To date, few contributions have been made concerning immunity and immune cells in venous thromboembolism. Recent reports in the literature show the involvement of two receptors, Dectin-1 [10] and TIM3 [11] in the immunity 
and inflammation conditions. Dectin-1 is expressed primarily by cells of myeloid lineage such as monocytes, macrophages, dendritic cells (DCs) and neutrophils. Dectin-1 acts as an antigen uptake receptor and triggers multiple signalling pathways. leading to NF- $\mathrm{kB}$, type I interferon (IFN) and/or inflammasome activation [11]. T cell immunoglobulin and mucin domain (Tim) molecules are type 1 transmembrane proteins expressed on various immune cells and are similar to PD-1/PD-L1/2 negative regulators of immune response. They include three human members (Tim-1, -3, -4) expressed in a variety of immune cells, such as natural killer (NK) cells, monocytes, macrophages and mast cells. During the innate immune response, Tim-3 promotes inflammation via tumour necrosis factor- $\alpha$ (TNF- $\alpha$ ) secretion by monocytes and antigen-presenting cells and enhances macrophage clearance of intracellular pathogens [12]. In this paper, we analyse the expression of these two transmembrane proteins in T cells from deep vein thrombosis of lower limbs (DVTLL) patients and control subjects.

\section{Experimental Section}

\subsection{Patient Recruitment}

Nine patients who were hospitalised for DVTLL in the General Medicine Unit of the University Hospital "Policlinico Rodolico" of Catania, Italy, were considered for the study. An equal number of healthy individuals, admitted to the non-invasive vascular medicine lab of our unit, was also enrolled. The patients' characteristics are reported in Table 1. DVTLL was diagnosed by ultrasonographic examination with an ultrasound system (US) equipped with a $4 \mathrm{Mhz}$ linear phased array probe (MyLaB 70, MyLab X vision, ESAOTE Italia Via di Caciolle, 15,50127 Firenze, Italy). The diagnosis criteria for DVTLL were based on an echogenic image of one of the deep veins of the lower limbs and incompressibility of the vein under US pressure (CUS positive test). When patients affected by DVTLL were enrolled for the study, they were treated with anti-thrombotic drugs (low-molecular-weight heparin) for one day. No anti-inflammatory drugs were administered to the patients. Patients were informed about the aim of study and were asked to give verbal informed consent to participate in the study and to provide blood samples. All subjects gave their informed consent before their inclusion in the study. The study was conducted in accordance with the Declaration of Helsinki, and the protocol was approved by the Ethics Committee of the Garibaldi Hospital (Catania, Italy; resolution n.23/2016/CECT2).

Table 1. Characteristics of deep vein thrombosis of lower limbs (DVTLL) patients and control subjects (Controls).

\begin{tabular}{cccc}
\hline & DVTLL Patients $(\boldsymbol{n}=\mathbf{9})$ & Controls $(\boldsymbol{n}=\mathbf{9})$ & $\begin{array}{c}\boldsymbol{p} \text {-Value Unpaired } \\
\boldsymbol{t} \text {-Test }\end{array}$ \\
\hline $\begin{array}{c}\text { Age } \\
(\text { mean } \pm \text { SD) }\end{array}$ & $65.44 \pm 18.12$ & $58.33 \pm 14.61$ & 0.285 \\
\hline $\begin{array}{c}\text { Weight Kg } \\
(\text { mean } \pm \text { SD) }\end{array}$ & $85.67 \pm 18.15$ & $74.00 \pm 19.58$ & 0.28 \\
\hline $\begin{array}{c}\text { Height cm } \\
(\text { mean } \pm \text { SD) }\end{array}$ & $176 \pm 9$ & $173+5.5$ & 0.33 \\
\hline $\begin{array}{c}\text { Body Mass Index-BMI } \\
(\text { mean } \pm \text { SD) }\end{array}$ & $27.51+5.11$ & $24.86+6.88$ & 0.17 \\
\hline Smoker $(\mathrm{n})$. & 3 & NA & NA \\
\hline
\end{tabular}

\subsection{Antibodies and Fluorophores}

The following five monoclonal primary antibodies directly conjugated with fluorophores according to the instrumental settings and available lasers were used: 
- anti-human CD3 antibody (clone UCHT1) conjugated with allophycocyanin (APC), a fluorophore with an excitation peak at $652 \mathrm{~nm}$ and an emission peak at $657.5 \mathrm{~nm}$ (Biolegend, San Diego, CA, USA cat 300439);

- anti-human CD4 (clone OKT4) and anti-human CD8 (SK1) fluorescein isothiocyanate (FITC), with an excitation peak at $495 \mathrm{~nm}$ and emission peak at $521 \mathrm{~nm}$ (Biolegend, San Diego, CA, USA cat 317408,344704$)$;

- $\quad$ anti-Dectin-1 (14E2) and anti-TIM3 (clone F38-2E2) were conjugated with phycoerythrin (PE) with an excitation peak at $565 \mathrm{~nm}$ and an emission peak at $573 \mathrm{~nm}$ (Biolegend, San Diego, CA, USA cat 345006, 355404).

\subsection{Cell Cultures for Antibody Validation}

Anti-human TIM3 and anti-human Dectin-1 antibodies were validated on two immortalised cell lines of leukaemia: HL60 and K562. Cell line HL60 (ATCC, CCL-240) was obtained from the peripheral blood of a patient affected by acute promyelocytic leukaemia, with myeloblastic morphology. K562 cells (ATCC, CCL-243) were obtained from the bone marrow of patients with chronic myelogenous leukaemia, with lymphoblastic morphology. Single staining was performed using anti-TIM3-PE and anti-Dectin-1-PE antibodies, according to the Biolegend protocol [www.biolegend.com]. Cells were cultured at high confluence in RPMI 1640 (w/HEPES w/Glutamax-I, cat 72400021, Gibco, Thermo Fisher Scientific) supplemented with 10\% fetal bovine serum (FBS), and 1\% penicillin/streptomycin. The cell cultures were incubated at $37{ }^{\circ} \mathrm{C}$ in a humidified atmosphere with $5 \% \mathrm{CO}_{2}$ and $95 \%$ air. The medium was changed twice a week. Cells were counted and resuspended at 1,000,000 cells $/ \mathrm{mL}$ and labelling with the antibodies was performed according to the Biolegend protocol.

\subsection{Sample Preparation}

In the early morning, fasting whole blood samples were collected using a Vacueteiner EDTA tube (Becton Dickinson, 1575 Airport Rd, Sumter, SC 29153, Stati Uniti USA), and immediately processed and analysed. White blood cells were isolated using the Biolegend protocol (https://www.biolegend.com, 8999 BioLegend Way, San Diego, CA 92121). The tube containing the blood was inverted several times to mix the contents. Briefly, the red blood cells were lysed using RBC lysis buffer followed by three washes with isotonic saline solution. Then, staining with the previously described five monoclonal fluorescent dye-coupled anti-human antibodies was conducted. For each patient, four aliquots of lymphocyte suspensions $(100 \mu \mathrm{L})$ were stained with antibodies using four different combinations of antibodies (10 $\mu$ L of each antibody): CD-3 + CD-4 + TIM-3 (A); CD-3 + CD-4 + Dectin-1 (B); CD-3 + CD-8 + TIM-3 (C); CD-3 + CD-8 + Dectin-1 (D). The mixture was kept in the dark, at $4{ }^{\circ} \mathrm{C}$, for half an hour. A wash step was performed to eliminate any antibody excess, and finally resuspended in cell staining buffer $(500 \mu \mathrm{L})$. Stained cells were analysed by cytofluorimetry. The analysis was conducted immediately to prevent signal loss due to fluorescent dye degradation. After staining, the cellular suspension was analysed on a flow cytometer (Amnis FlowSight Millipore, Merck KgaA, Darmstadt, Germany), and the results were analysed using Image Data Exploration and Analysis (IDEAS) software (Amnis part of EMD Millipore, Seattle, WA, USA) as previously reported [13] and as described in detail in the next paragraph.

The algorithms in the IDEAS software create two types of functions: mask and feature. Mask refers to the set of pixels that contain the region of interest, and feature refers to calculated values using the pixel intensities of the image. Our analysis started by distinguishing the single cells from debris and cell aggregates by creating a scatter plot of "Area" versus "Aspect ratio". The feature "Area" calculates the square microns of a given mask, while "Aspect ratio" is the ratio of the minor axis and major axis and describes how round or long an object is. The "FlowSight" is also equipped with a dedicated laser for side scattering at $785 \mathrm{~nm}$, a useful tool to obtain information about cellular morphology. Therefore, creating a "single cell" gate, a scatter plot graph of "Side scatter intensity" vs. "Area", 
it was possible to identify, based on morphology and area, the human peripheral blood mononuclear cells (PBMCs). Since the anti-human CD3 antibody conjugated with allophycocyanin (APC) binds the $\mathrm{CD} 3$ antigen expressed on the membrane surface of T lymphocytes (Figure 1), a scatter plot of "Side scatter intensity" vs. "APC intensity" was generated in order to isolate the lymphocytes from other PMBCs. The CD4 and CD8 antibodies, both conjugated with FITC, distinguished, in the scatter plot graphs of "APC intensity" vs. "FITC intensity" created based on the lymphocyte gate, two different types of lymphocyte populations: $\mathrm{CD}^{+}$and $\mathrm{CD}^{+}$cells (T helper cells) or $\mathrm{CD}^{+}$and $\mathrm{CD} 8^{+}$positive cells (suppressor $\mathrm{T}$ cells). For each graph, it was possible to recognise two types of populations $\mathrm{CD}^{+} / \mathrm{CD}^{+}$(or $\mathrm{CD}^{+} / \mathrm{CD}^{-}$) and $\mathrm{CD}^{+} / \mathrm{CD}^{+}$(or $\mathrm{CD}^{+} / \mathrm{CD}^{-}$). On the double-positive gates $\left(\mathrm{CD}^{+} / \mathrm{CD}^{+}\right.$or $\left.\mathrm{CD}^{+} / \mathrm{CD}^{+}\right)$we finally created the histogram "Phycoerythrin (PE) intensity" to analyse the percentage of positive cells for Dectin-1 or TIM3 (both corresponding antibodies being conjugated with PE).

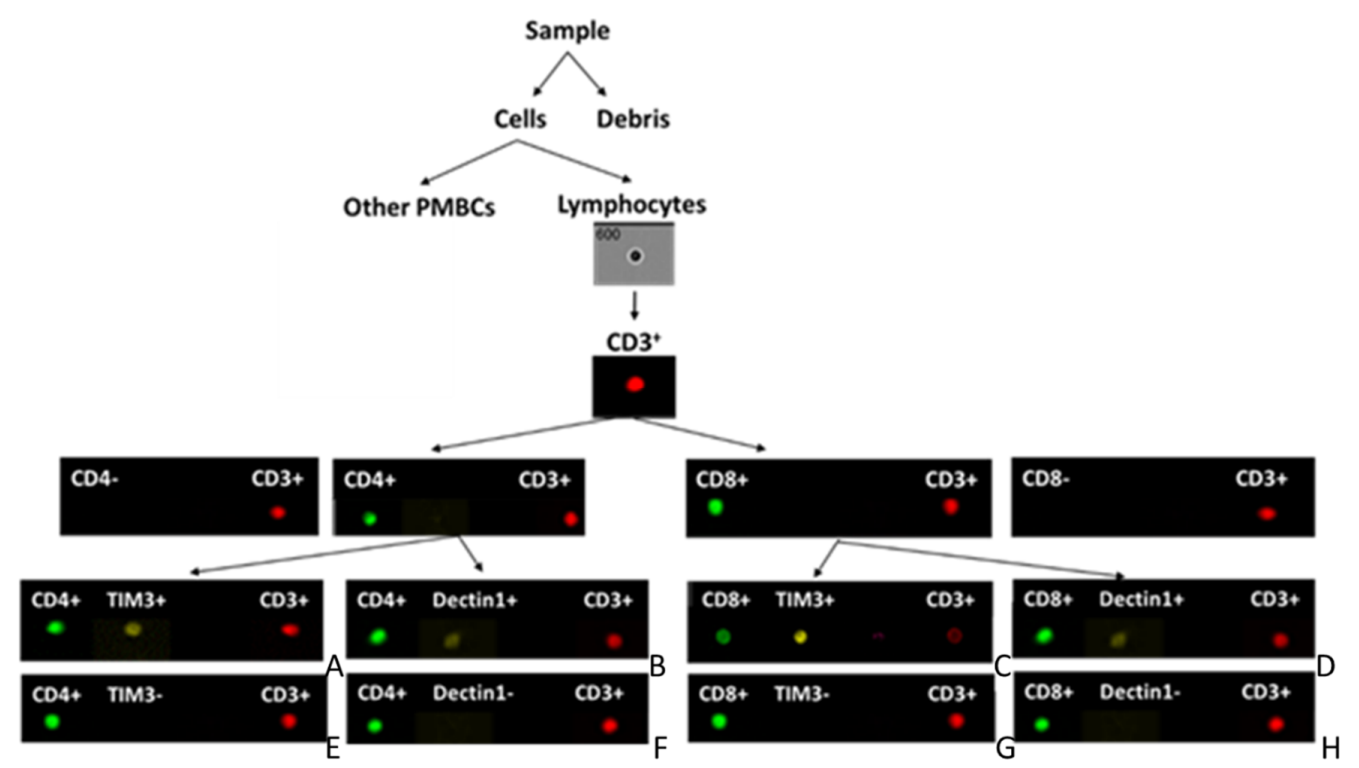

Figure 1. Flow cytofluorimetric analysis workflow. The image shows the sequential procedure and the microphotographs of stained cells $(\mathbf{A}-\mathbf{H})$ using five different monoclonal fluorescent dye-coupled anti-human antibodies and analysed by flow cytometry (Amnis FlowSight). For each patient, four aliquots of lymphocyte suspensions $(100 \mu \mathrm{L})$ were stained with antibodies using four different combinations $(10 \mu \mathrm{L}$ of each antibody). Representative stained cells (event) for each of the four combinations are shown: CD $-3^{+}$CD $-4^{+}$TIM- $^{+}(\mathbf{A})$; CD $-3^{+}$CD $-4^{+}$Dectin- $1^{+}$(B); CD $-3^{+}$CD $-8^{+}$ $\mathrm{TIM}^{+} 3^{+}(\mathrm{C}) ; \mathrm{CD}-3^{+}$CD-8 ${ }^{+}$Dectin- $1^{+}(\mathrm{D})$. Tim3 ${ }^{-}$and Dectin- $1^{-}$cells are also shown: CD3 ${ }^{+} \mathrm{CD}-4^{+}$

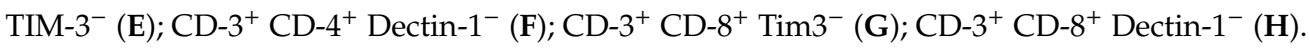

\subsection{Statistical Analysis}

Statistical analysis was carried out using GraphPad Prism 6 (Graphpad Software Inc., La Jolla, CA, USA). A parametric unpaired $t$-test was used for the data reported in Table 1. A non-parametric $t$-test for unpaired data (Mann-Whitney U test) was performed on the data from DVTLL patients and the control group (Figure 2 and Table 2). Significance was set at $p<0.05$. 

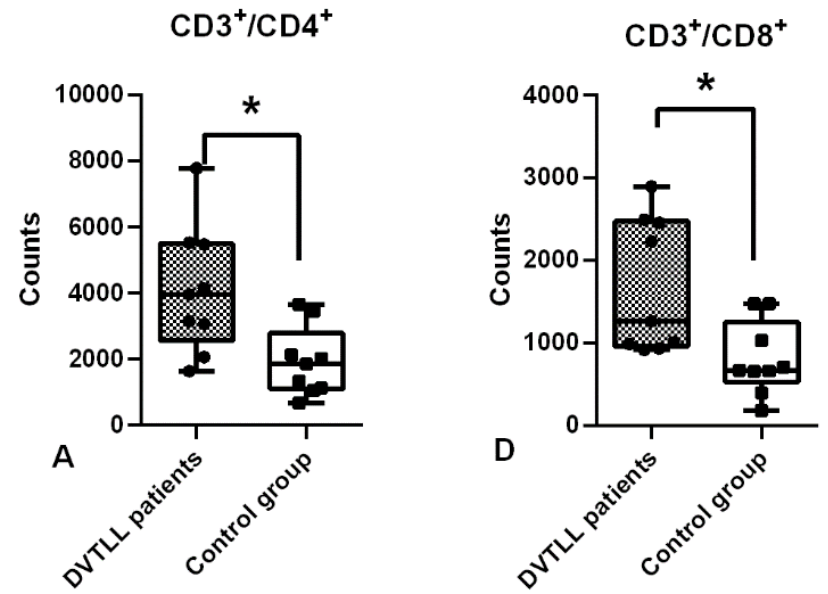

$\mathrm{CD}^{+} / \mathrm{TIM}^{+}$

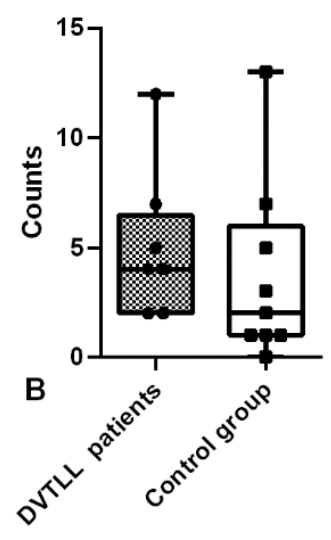

$\mathrm{CD8}^{+} / \mathrm{TIM}^{+}$

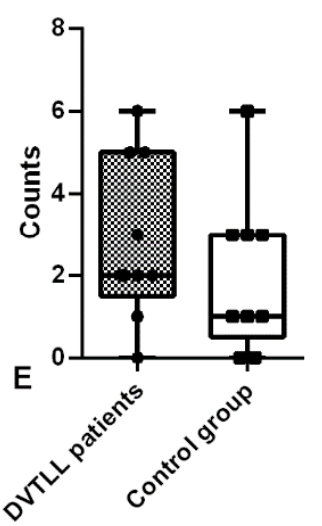

CD4 ${ }^{+} /$Dectin $-1^{+}$
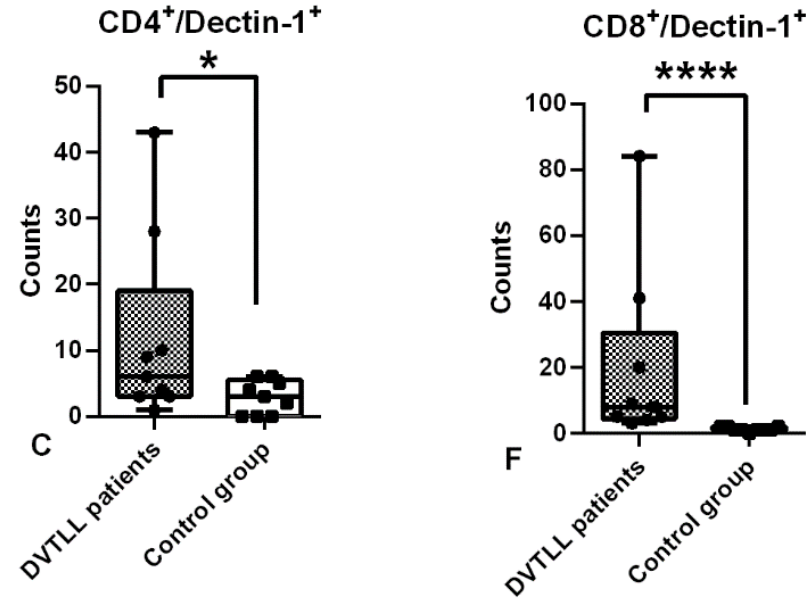

Figure 2. Expression of TIM3 and Dectin- 1 in $\mathrm{CD}^{+}, \mathrm{CD}^{+}$and $\mathrm{CD} 8^{+} \mathrm{T}$ lymphocytes belonging to DVTLL patients and healthy controls was analysed by flow cytofluorimetric analysis. The number of $\mathrm{CD}^{+} / \mathrm{CD}^{+}$and $\mathrm{CD}^{+} / \mathrm{CD}^{+}$cells was higher in DVTLL patients $(\mathbf{A}, \mathbf{D})$. No differences were observed for $\mathrm{CD}^{+} / \mathrm{TIM}^{+}$and $\mathrm{CD}^{+} / \mathrm{TIM}^{+}$cells between DVTLL patients and controls $(\mathbf{B}, \mathrm{E})$. The number of $\mathrm{CD}^{+}$and $\mathrm{CD}^{+}$cells expressing Dectin-1 (C,F) was significantly higher in DVTLL patients. Statistical analysis was performed by a Mann-Whitney test. ${ }^{*} p<0.05$; ${ }^{* * *} p<0.0001$. 
Table 2. Total cell counts for each stained subpopulation and percentages of stained $\mathrm{CD}^{+}$ subpopulations calculated with respect to each category in DVTLL patients and in health controls are reported as mean and median. Statistical analysis for DVTLL patients compared to controls was performed by a Mann-Whitney test. Statistically significant values $(p<0.05)$ are underlined.

\begin{tabular}{|c|c|c|c|c|c|c|c|}
\hline & \multicolumn{3}{|c|}{ DVTLL $(n=9)$} & \multicolumn{3}{|c|}{ Controls $(n=9)$} & \multirow[b]{2}{*}{$\begin{array}{c}p \text {-Value } \\
\text { (Mann-Whitney } \\
t \text {-Test) }\end{array}$} \\
\hline & Mean & Median & $\pm \mathrm{SD}$ & Mean & Median & $\pm \mathrm{SD}$ & \\
\hline $\begin{array}{c}\text { T cell } \\
\text { lymphocyte } \\
\text { count }\left(\mathrm{CD}^{+}\right)\end{array}$ & 5283.9 & 4473.3 & 1680.8 & 1936.6 & 1996.5 & 573.4 & $\leq 0.0001$ \\
\hline $\begin{array}{c}\mathrm{T} \\
\text { Lymphocytes } \\
\left(\mathrm{CD}^{+}\right)(\text {as \% } \\
\text { of PBMC) }\end{array}$ & 19.0 & 15.6 & 6.2 & 15.2 & 15.5 & 3.1 & 0.39 \\
\hline $\begin{array}{l}\mathrm{CD}^{+} / \mathrm{CD}^{+} \\
\text {count }\end{array}$ & 4089.6 & 3962.0 & 1926.2 & 1924.7 & 1854.5 & 1045.5 & $\underline{0.01}$ \\
\hline $\begin{array}{c}\mathrm{CD}^{+} / \mathrm{CD}^{+} \\
\left(\text {as } \% \text { of } \mathrm{CD}^{+} \text {) }\right.\end{array}$ & 63.7 & 65.3 & 10.1 & 61.9 & 61.3 & 11.3 & 0.62 \\
\hline $\begin{array}{c}\mathrm{CD}^{+} / \mathrm{CD}^{+} \\
\text {count }\end{array}$ & 1686.2 & 1263.5 & 813.2 & 805.3 & 667.5 & 441.9 & $\underline{0.018}$ \\
\hline $\begin{array}{c}\mathrm{CD}^{+} / \mathrm{CD}^{+} \\
\text {as } \% \text { of } \mathrm{CD}^{+} \text {) }\end{array}$ & 27.8 & 26.4 & 6.7 & 28.4 & 29.3 & 9.7 & $>0.99$ \\
\hline $\begin{array}{l}\mathrm{CD}^{+} / \mathrm{TIM}^{+} \\
\text {count }\end{array}$ & 4.75 & 4.0 & 3.41 & 3.7 & 2.0 & 4.2 & 0.27 \\
\hline $\begin{array}{c}\mathrm{CD}^{+} / \mathrm{TIM}^{+} \\
\text {(as \% of } \\
\left.\mathrm{CD}^{+} / \mathrm{CD}^{+}\right)\end{array}$ & 0.1 & 0.1 & 0.4 & 0.2 & 0.1 & 0.2 & 0.89 \\
\hline $\begin{array}{l}\mathrm{CD}^{+} / \mathrm{TIM}^{+} \\
\text {count }\end{array}$ & 2.9 & 2.0 & 2.0 & 2.0 & 1.0 & 1.9 & 0.41 \\
\hline $\begin{array}{c}\mathrm{CD}^{+} / \mathrm{TIM}^{+} \\
(\text {as } \% \text { of } \\
\left.\mathrm{CD}^{+} / \mathrm{CD}^{+}\right)\end{array}$ & 0.3 & 0.2 & 0.2 & 0.3 & 0.2 & 0.3 & 0.98 \\
\hline $\begin{array}{l}\mathrm{CD} 4^{+} / \text {Dectin- }^{+} \\
\text {count }\end{array}$ & 11.9 & 6.0 & 14.2 & 2.9 & 3.0 & 2.5 & $\underline{0.027}$ \\
\hline $\begin{array}{l}\mathrm{CD}^{+} / \mathrm{Dectin}^{-} 1^{+} \\
(\text {as \% of } \\
\left.\mathrm{CD}^{+} / \mathrm{CD}^{+}\right)\end{array}$ & 0.3 & 0.1 & 0.4 & 0.2 & 0.1 & 0.2 & 0.65 \\
\hline $\begin{array}{l}\mathrm{CD}^{+} / \text {Dectin- }^{+} \\
\text {count }\end{array}$ & 19.9 & 8.0 & 26.9 & 1.2 & 1.0 & 0.7 & $\leq 0.0001$ \\
\hline $\begin{array}{l}\mathrm{CD}^{+} / \text {Dectin- } 1^{+} \\
\text {(as \% of } \\
\left.\mathrm{CD}^{+} / \mathrm{CD}^{+}\right)\end{array}$ & 1.0 & 0.7 & 1.1 & 0.2 & 0.2 & 0.3 & $\underline{0.037}$ \\
\hline
\end{tabular}

\section{Results}

K562 and HL60 cell lines were analysed to validate the expression of TIM3 and Dectin-1 in human haematopoietic cells. K562 is a highly undifferentiated human erythroleukaemia cell population belonging to chronic myelogenous leukaemia (CML). K-562 blasts are multipotential, haematopoietic malignant cells that spontaneously differentiate into recognisable progenitors of erythrocytic, granulocytic and monocytic series. A cytofluorimeter assay showed high median values of 78.0 and 75.5 for TIM3 and Dectin-1, respectively (Table 3). HL60 is a cell line derived from a 36-year-old woman affected by acute promyelocytic leukaemia and the cells predominantly have a neutrophilic promyelocytic morphology. The cytofluorimeter assay in the last cell line also showed an equal distribution of both surface molecules, even if the median values were lower: 12.4 and 12.1 were positive for TIM3 and Dectin-1, respectively (Table 3). 
Table 3. Cytofluorimeter assay on HL-60 and K-562 cell lines. Percentages of cells expressing TIM3 and Dectin- 1 are reported as median and interquartile range (IQR) calculated for three experiments.

\begin{tabular}{ccc}
\hline Surface Molecule & Cell Line & Median (IQR) \\
\hline \multirow{2}{*}{ TIM3 } & HL60 & $12.4(1.7)$ \\
\cline { 2 - 3 } & K562 & $78.0(5.5)$ \\
\hline \multirow{2}{*}{ Dectin-1 } & HL60 & $12.1(2.6)$ \\
\cline { 2 - 3 } & K562 & $75.5(5)$ \\
\hline
\end{tabular}

The analysis performed on blood cells purified from DVTLL patients and control subjects revealed that the total count of $\mathrm{CD}^{+} \mathrm{T}$ lymphocytes isolated from peripheral blood was higher in DVTLL patients than the healthy control group, the increase was two-fold as shown by the median values (4473.3 vs. $1996.5, p$-value $<0.0001$ ) (Table 2). Furthermore, $\mathrm{CD}^{+} \mathrm{T}$ helper cells and cytotoxic CD8 ${ }^{+}$ $\mathrm{T}$ cells were counted. The analysis demonstrated that, also in this case, both $\mathrm{T}$ cell populations showed higher values in DVTLL patients (mean, median, SD are shown in Table 2), two times more than in the healthy control group $\left(\mathrm{CD}^{+} / \mathrm{CD}^{+} p\right.$-value $=0.01 ; \mathrm{CD}^{+} / \mathrm{CD}^{+} p$-value $=0.018$, Table 2 , Figure 2A,D). Subsequently, the expression of TIM3 and Dectin- 1 on the surfaces of CD4 ${ }^{+}$and CD8 ${ }^{+}$ cells was evaluated. As expected, the number of $\mathrm{TIM}^{+}$on $\mathrm{CD} 4^{+}$and $\mathrm{CD} 8^{+}$cells was low. TIM3 levels did not show significant differences in expression on $\mathrm{T}$ helper cells $\left(\mathrm{CD} 4^{+}\right)$and cytotoxic $\mathrm{T}$ cells $\left(\mathrm{CD}^{+}\right)$of DVTLL patients (Figure 2B,E). On the contrary, a significant increase in CD4 $4^{+} /$Dectin $-1^{+}$cells ( $p$-value 0.027 , Table 2; Figure 2C) and CD8 $8^{+} /$Dectin- $1^{+}$cells ( $p$-value $<0.0001$, Table 2 , Figure 2F) was observed in DVTLL patients compared to healthy controls.

\section{Discussion}

This is the first paper focusing on Dectin-1 and TIM3 measured in peripheral blood cells in DVTLL patients using the cytofluorimetric assay technique and an instrument that combines a traditional flow cytometer with a powerful and highly sensitive microscopy (FlowSight imaging flow cytometer, Amnis, Merck Millipore, Burlington, MA, USA). The three following lasers were used: $488 \mathrm{~nm}$ (blue), $561 \mathrm{~nm}$ (green) and $642 \mathrm{~nm}$ (red) wavelengths. Moreover, two channels were used for the brightfield. A single cell was placed in the flow chamber and when it passed through the detector of the instrument, the brightfield image of the cell and the emitted fluorescence were recorded. Another single channel was used to reveal the side-scattering (SSC) signal, which, together with the signal of the brightfield, gave information on cell morphology. The interesting feature of this instrument is the possibility to select a region on the dot-plot graph and to watch, on each channel, the relative signal of expression of proteins localised in the cell membrane, nucleus and cytosol. Figure 1 shows the workflow and the images of single cells detected for each of the single antibodies used in the analysis.

In this study, we investigated Dectin-1 [10] and TIM3 [11] expression in T lymphocytes in DVTLL patients. Indeed, Dectin-1 and TIM3 are known to play a role in several pathological conditions including infection, regulation of inflammation, allergy, transplantation tolerance, cancer, cardiovascular disease and autoimmune diseases. Our study revealed a significantly increased number of Thelper $\mathrm{CD}^{+}$and T cytotoxic CD8 $8^{+}$cells in DVTLL, as well as an increased number of $\mathrm{CD}^{+}$and $\mathrm{CD}^{+}$cells expressing Dectin-1. We found a similar trend for TIM3 expression in both cellular subtypes, although the increase did not reach statistical significance.

It is well known that Dectin-1 is a receptor belonging to "C-type lectin domain family 7 member A" encoded by the CLEC7A gene (Cr12p13.2). This receptor recognises the $\beta$-glucans found in the cell walls of plants and fungi, including Candida albicans. Dectin-1 activation promotes both "T helper type 1" (Th-1) and "T helper type 17" (Th-17) cells in the production of interleukin (IL)-17. IL-17 is involved in cellular innate immune responses by dendritic cells that are needed in protection against fungi [14-17]. The Dectin-1 receptor is also recognised by endogenous ligands including vimentin [18], galactosylated immunoglobulins [19], and galectins [20]. Dectin-1 is highly expressed in monocytes, 
macrophages and neutrophils and, conversely, it is expressed to a lesser extent in B cells, T cells and dendritic cells [21], and Dectin-1 activation can influence the development of CD4 and CD8 T cells. High expression and activation of Dectin-1 causes the release of pro-inflammatory molecules [22]. Activation of the Dectin-1 receptor through spleen tyrosine kinase (SYK) protein, caspase recruitment domain 9 (CARD9) protein, adaptor proteins Bcl-10, MALT1 and complex ERK-TNK-P38 induces both NF-KB activation and the transcription of various inflammatory cells including IL-12 and TNF- $\alpha$ in T helper cells $[18,23,24]$. Pro-inflammatory cytokine IL-12 stimulates the differentiation of $\mathrm{CD} 4^{+}$lymphocytes into Th- 1 lymphocytes; on the other hand, TIM3 has its expression restricted to inflammatory IFN- $\gamma$ producing "type 1" CD4 T cells and CD8 T cells [11]. Th-1 lymphocytes are capable of activating macrophagic activity, thus they are capable of starting the phagocytosis of pathogens, and then activating other forms of defence. Furthermore, the IL-12 upregulation potentiated the cytotoxic activity of CD-8 $8^{+}$macrophages $\left(\mathrm{CD}-3^{-} / \mathrm{CD}-4^{-}\right)$[25]. Luther et al. 2016 [9] demonstrated that helper $\mathrm{CD}-4^{+}$and cytotoxic $\mathrm{CD}-8^{+} \mathrm{T}$ cells are able to infiltrate the thrombus during and after a DVT event. Effector memory $\mathrm{T}$ cells $\left(\mathrm{T}_{\mathrm{EM}}\right)$ continue to produce INF- $\gamma$ in an antigen-independent manner in order to support aseptic inflammation events, such as those revealed in the DVT condition. The activation of $\mathrm{T}_{\mathrm{EM}}$ cells in the thrombus leads to the recruitment of neutrophils and monocytes, delaying thrombus resolution [9]. The higher expression of Dectin- 1 observed in both CD4 ${ }^{+}$and CD8 ${ }^{+}$ cells suggests the involvement of Dectin-1 and its effects on Th1/Th17 cells in DVTLL. In conclusion, we suggest that there is a link between the latent chronic inflammation characterising thromboembolism and the immune system and that the role of both native and adaptive immunity should be further investigated in venous thromboembolism.

Author Contributions: Conceptualisation, V.B. and S.S.S.; methodology, S.N.; G.S.; validation, V.B.; S.N.; G.S.; formal analysis, V.B.; S.N.; G.S.; investigation, V.B.; S.N.; G.S.; resources, V.B.; D.F.C.; S.S.S.; writing一 original draft preparation, V.B.; S.S.S.; S.N.; G.S.; writing—review and editing, V.B.; S.S.S.; D.F.C.; funding acquisition, V.B.; S.S.S. All authors have read and agreed to the published version of the manuscript.

Funding: This research received no external funding. The present work is supported by the University of Catania, "linea 4 ".

Acknowledgments: The authors acknowledge the PON project Bio-nanotech Research and Innovation Tower (BRIT), financed by the Italian Ministry for Education, University and Research (MIUR) (Grant no. PONa3_00136) for flow cytometer support. We wish to thank the Scientific Bureau of the University of Catania for language support.

Conflicts of Interest: The authors declare no conflict of interest.

$\begin{array}{ll}\text { Abbreviations } & \\ \text { APC cells } & \text { Antigen-presenting cells } \\ \text { APC } & \text { Allophycocyanin } \\ \text { Bcl-10 } & \text { B-cell lymphoma/leukaemia 10 } \\ \text { CARD9 } & \text { Caspase recruitment domain 9 } \\ \text { CD3 } & \text { Cluster of differentiation 3 } \\ \text { CD4 } & \text { Cluster of differentiation } 4 \\ \text { CD8 } & \text { Cluster of differentiation 8 } \\ \text { CLEC7A } & \text { C-Type lectin domain-containing 7A } \\ \text { CML } & \text { Chronic myelogenous leukaemia } \\ \text { COPD } & \text { Chronic obstructive pulmonary disease } \\ \text { DVT } & \text { Deep vein thrombosis } \\ \text { DVTLL } & \text { Deep vein thrombosis of lower limbs } \\ \text { ERK } & \text { Extracellular signal-related kinases } \\ \text { FITC } & \text { Fluorescein isothiocyanate } \\ \text { HAVCR2 } & \text { Hepatitis A virus cellular receptor 2 }\end{array}$




$\begin{array}{ll}\text { (IL)-12 } & \text { Interleukin } 12 \\ \text { (IL)-17 } & \text { Interleukin } 17 \\ \text { INF } \gamma & \text { Interferon } \gamma \\ \text { MALT1 } & \text { Mucosa-associated lymphoid tissue lymphoma translocation protein } 1 \\ \text { NF-kB } & \text { Nuclear factor kappa light-chain enhancer of activated B cells } \\ \text { NK } & \text { Natural killer cells } \\ \text { PBMC } & \text { Peripheral blood mononuclear cells } \\ \text { PE } & \text { Phycoerythrin } \\ \text { SSC } & \text { Side-scattering } \\ \text { SYK } & \text { Spleen tyrosine kinase protein } \\ \text { TEM cells } & \text { Effector memory T cells } \\ \text { Th-1 } & \text { T helper type } 1 \\ \text { Th-17 } & \text { T helper type } 17 \\ \text { TIM } & \text { T cell immunoglobulin and mucin domain } \\ \text { TNF- } \alpha & \text { Tumour necrosis factor- } \alpha \\ \text { VTE } & \text { Venous thromboembolism }\end{array}$

\section{References}

1. Kim, V.; Goel, N.; Gangar, J.; Zhao, H.; Ciccolella, D.E.; Silverman, E.K.; Crapo, J.D.; Criner, G.J.; The High-Risk-COPD Screening Study Group. Risk Factors for Venous Thromboembolism in Chronic Obstructive Pulmonary Disease. Chronic Obstr. Pulm. Dis. 2014, 1, 239-249. [CrossRef] [PubMed]

2. Børvik, T.; Brækkan, S.K.; Enga, K.; Schirmer, H.; Brodin, E.E.; Melbye, H.; Hansen, J.B. COPD and risk of venous thromboembolism and mortality in a general population. Eur. Respir. J. 2016, 47, 473-481. [CrossRef] [PubMed]

3. Majoor, C.J.; Kamphuisen, P.W.; Zwinderman, A.H.; Ten Brinke, A.; Amelink, M.; Rijssenbeek-Nouwens, L.; Sterk, P.J.; Büller, H.R.; Bel, E.H. Risk of deep vein thrombosis and pulmonary embolism in asthma. Eur. Respir. J. 2013, 42, 655-661. [CrossRef] [PubMed]

4. Potaczek, D.P. Links between allergy and cardiovascular or hemostatic system. Int. J. Cardiol. 2014, 170, 278-285. [CrossRef] [PubMed]

5. Byrnes, J.R.; Wolberg, A.S. New findings on venous thrombogenesis. Hamostaseologie 2017, 37, $25-35$. [CrossRef] [PubMed]

6. Budnik, I.; Brill, A. Immune Factors in Deep Vein Thrombosis Initiation. Trends Immunol. 2018, 39, 610-623. [CrossRef] [PubMed]

7. Mukhopadhyay, S.; Johnson, T.A.; Duru, N.; Buzza, M.S.; Pawar, N.R.; Sarkar, R.; Antalis, T.M. Fibrinolysis and Inflammation in Venous Thrombus Resolution. Front. Immunol. 2019, 10, 1348. [CrossRef]

8. Thachil, J. Deep vein thrombosis. Hematology (Amsterdam, The Netherlands) 2014, 19, 309-310. [CrossRef] [PubMed]

9. Luther, N.; Shahneh, F.; Brähler, M.; Krebs, F.; Jäckel, S.; Subramaniam, S.; Stanger, C.; Schönfelder, T.; Kleis-Fischer, B.; Reinhardt, C.; et al. Innate Effector-Memory T-Cell Activation Regulates Post-Thrombotic Vein Wall Inflammation and Thrombus Resolution. Circ. Res. 2016, 119, 1286-1295. [CrossRef] [PubMed]

10. Tone, K.; Stappers, M.; Willment, J.A.; Brown, G.D. C-type lectin receptors of the Dectin-1 cluster: Physiological roles and involvement in disease. Eur. J. Immunol. 2019, 49, 2127-2133. [CrossRef] [PubMed]

11. Tang, R.; Rangachari, M.; Kuchroo, V.K. Tim-3: A co-receptor with diverse roles in T cell exhaustion and tolerance. Semin. Immunol. 2019, 42, 101302. [CrossRef] [PubMed]

12. Foks, A.C.; Ran, I.A.; Wasserman, L.; Frodermann, V.; Ter Borg, M.N.; de Jager, S.C.; van Santbrink, P.J.; Yagita, H.; Akiba, H.; Bot, I.; et al. T-cell immunoglobulin and mucin domain 3 acts as a negative regulator of atherosclerosis. Arter. Thromb. Vasc. Biol. 2013, 33, 2558-2565. [CrossRef] [PubMed]

13. Cardullo, N.; Pulvirenti, L.; Spatafora, C.; Musso, N.; Barresi, V.; Condorelli, D.F.; Tringali, C. Dihydrobenzofuran Neolignanamides: Laccase-Mediated Biomimetic Synthesis and Antiproliferative Activity. J. Nat. Prod. 2016, 79, 2122-2134. [CrossRef] [PubMed] 
14. LeibundGut-Landmann, S.; Gross, O.; Robinson, M.J.; Osorio, F.; Slack, E.C.; Tsoni, S.V.; Schweighoffer, E.; Tybulewicz, V.; Brown, G.D.; Ruland, J.; et al. Syk- and CARD9-dependent coupling of innate immunity to the induction of T helper cells that produce interleukin 17. Nat. Immunol. 2007, 8, 630-638. [CrossRef]

15. Hohl, T.M.; Rivera, A.; Pamer, E.G. Immunity to fungi. Curr. Opin. Immunol. 2006, 18, 465-472. [CrossRef] [PubMed]

16. Huysamen, C.; Brown, G.D. The fungal pattern recognition receptor, Dectin-1, and the associated cluster of C-type lectin-like receptors. FEMS Microbiol. Lett. 2009, 290, 121-128. [CrossRef] [PubMed]

17. Rogers, H.; Williams, D.W.; Feng, G.J.; Lewis, M.A.; Wei, X.Q. Role of bacterial lipopolysaccharide in enhancing host immune response to Candida albicans. Clin. Dev. Immunol. 2013, 2013, 320168. [CrossRef]

18. Castoldi, A.; Andrade-Oliveira, V.; Aguiar, C.F.; Amano, M.T.; Lee, J.; Miyagi, M.T.; Latância, M.T.; Braga, T.T.; da Silva, M.B.; Ignácio, A.; et al. Dectin-1 Activation Exacerbates Obesity and Insulin Resistance in the Absence of MyD88. Cell Rep. 2017, 19, 2272-2288. [CrossRef] [PubMed]

19. Karsten, C.M.; Pandey, M.K.; Figge, J.; Kilchenstein, R.; Taylor, P.R.; Rosas, M.; McDonald, J.U.; Orr, S.J.; Berger, M.; Petzold, D.; et al. Anti-inflammatory activity of IgG1 mediated by Fc galactosylation and association of Fc $\gamma$ RIIB and dectin-1. Nat. Med. 2012, 18, 1401-1406. [CrossRef] [PubMed]

20. Daley, D.; Mani, V.R.; Mohan, N.; Akkad, N.; Ochi, A.; Heindel, D.W.; Lee, K.B.; Zambirinis, C.P.; Pandian, G.; Savadkar, S.; et al. Dectin 1 activation on macrophages by galectin 9 promotes pancreatic carcinoma and peritumoral immune tolerance. Nat. Med. 2017, 23, 556-567. [CrossRef]

21. Willment, J.A.; Lin, H.H.; Reid, D.M.; Taylor, P.R.; Williams, D.L.; Wong, S.Y.C.; Gordon, S.; Brown, G.D. Dectin-1 expression and function are enhanced on alternatively activated and GM-CSF-treated macrophages and are negatively regulated by IL-10, dexamethasone, and lipopolysaccharide. J. Immunol. 2003, 171, 6297. [CrossRef] [PubMed]

22. Ganesan, S.; Rathinam, V.; Bossaller, L.; Army, K.; Kaiser, W.J.; Mocarski, E.S.; Dillon, C.P.; Green, D.R.; Mayadas, T.N.; Levitz, S.M.; et al. Caspase-8 modulates dectin-1 and complement receptor 3-driven IL-1 $\beta$ production in response to $\beta$-glucans and the fungal pathogen, Candida albicans. J. Immunol. 2014, 193, 2519-2530. [CrossRef] [PubMed]

23. Gringhuis, S.I.; den Dunnen, J.; Litjens, M.; van der Vlist, M.; Wevers, B.; Bruijns, S.C.; Geijtenbeek, T.B. Dectin-1 directs T helper cell differentiation by controlling noncanonical NF-kappaB activation through Raf-1 and Syk. Nat. Immunol. 2009, 10, 203-213. [CrossRef] [PubMed]

24. Ostrop, J.; Lang, R. Contact, Collaboration, and Conflict: Signal Integration of Syk-Coupled C-Type Lectin Receptors. J. Immunol. 2017, 198, 1403-1414. [CrossRef] [PubMed]

25. Wagener, M.; Hoving, J.C.; Ndlovu, H.; Marakalala, M.J. Dectin-1-Syk-CARD9 Signaling Pathway in TB Immunity. Front. Immunol. 2018, 9, 225. [CrossRef]

Publisher's Note: MDPI stays neutral with regard to jurisdictional claims in published maps and institutional affiliations.

(C) 2020 by the authors. Licensee MDPI, Basel, Switzerland. This article is an open access article distributed under the terms and conditions of the Creative Commons Attribution (CC BY) license (http://creativecommons.org/licenses/by/4.0/). 